\title{
Traditional Paradise Gardens of Mauritian Spain of XIII-XV Centuries
}

\author{
Sadikova Sitora-bonu \\ Samarkand State Architectural and Civil Engineering Institute, Samarkand, Uzbekistan
}

\begin{abstract}
The article throws light upon the existence and development of "Paradise garden" theory. Describes the features of traditional Islamic gardens of the Mauritanian architecture and gardening art - in the strengthened residences of Grenadian emirs Alhambra and the Generalife.
\end{abstract}

Keywords: traditional, gardens, Mauritania architecture and gardening art

\section{Introduction}

Art of formation of a traditional Islamic garden harmony between accurate geometry of surrounding architecture, the organization of water devices and planting of trees is the cornerstone, of bushes and flowers. The unity is reached through an order and in the concept of traditional Islamic gardens there are no borders between sacred and wordly, everything makes a deep meaning and is captured by sacred symbolism.

Understanding that Paradise - it the Garden goes from the Sumer period (4000 BC) in Mesopotamia. According to Gilgamesh's epos in Babylon (2700 BC) has been described "public paradise". In the Koran these gardens are called "Jannat Al - Firdaus" where "Jannat" means a garden, and "Firdaus" - paradise. The English word paradise has come from the name of gardens of a ancient Persian civilization of Sasanids and Akhemenids' dynasties (III-IV century BC) from their "payridez" (the hunting parks surrounded with a wall) where "payr" - means around, and "deza" - a wall. Thus, received the territory isolated from noisy environment for the purpose of organized protection of the fertile man - made earth. Primary nature of "paradise" is the secret hidden life form in a fine splendid garden that corresponds to the most intimate in human's soul of the true believer -to desire to get in "Jannat"( in Paradise).

Ancient traditional gardens, with their four-part plans, have arisen as a shadow of Paradise gardens on the earth from a combination of an ancient pre-Islamic Persian prototype. The number four is symbolical: four elements, four season ... Really in plans of the majority of traditional gardens the number four such as prevails: Alhambra, Alkasar, Seville in the southern Spain of XI-XIII century, Chakhar-a bug in Isfahan (XVI century), Samarkand (XV century), Gardens around Humayun's Tombs and Taj Mahal in India, Morokko gardens, Syria.

Throughout seven centuries (VII-XIVc.) Muslim Spain was one of the largest centers of culture of Arabs, and was famous for outstanding philosophers: Ibn Tufayl, Ibn Roshd. Treatises of plants of Abu-Hanif ad Dinaveri (apprx. 820-895yy.), the father of the Arab botany - Ibn Vafid (999-1075yy.), works of his receivers Ibn Bassal and Abn al-Avval, along with Aristotle and Platon's doctrines translated to the Arab language have formed a basis of garden art of Mauritian Spain. A bright, striking example of that was the creation of 50 gardens from which only gardens in Alhambra remained - the residence of the Granada's Emirs. For example: the «Myrtaceous» and «Lion's yard» in Alhambra; «the Yard with the Channel» and «Sultaness's garden» in Generalife; a garden Casas de Contrasien - in Kardobe (1238-1492). Everywhere alternation of the opened and closed spaces, aspiration to create lonely green court yard with the balanced, harmonious composition of architecture, with plants and water that is typical for the Muslim "hidden architecture" is traced.

Mauritian art - being unique art style, it has developed and has blossomed in North Africa and Andalusia - the Southern Spain, in the XI-XV centuries and has most brightly proved in architecture and landscape gardening art.

Alhambra: The strengthened residence of Granada emirs built in the XIII-XIV centuries on the suburb of the Spanish city of Granada. (Figure 1). This monument of art and at the same time a typical example of the traditional "hidden architecture" is the real pearl of Mauritian architecture including gardens. Having subdued in the XIII century huge water flow from glaciers Sierra-Nevada, architects at court of a Nasrid dynasty have built a thin and skillful system of aqueducts and water tanks on the mountain «of the Sun»[1] over Alhambra. By means of these aqueducts gardens at palaces of Alhambra were provided with water.

In the XIII century, the first sultan of the Nasrid dynasty Muhammad Ibn Al-Akhmar has been constructed the palace among shady gardens, through the ages; each of the subsequent governors of this dynasty will introduce something the individual to Alhambra.

The American traveler Irving noted: "The rich water delivered from mountains by means of ancient Mauritian aqueducts circling in the palace, supplying baths and fish ponds, spurts in halls or murmurs along the sidewalks. Having provided with water a complex of the emir and gardens and pastures, the stream directs on the long road conducting to the city, murmuring in streamlets, being promptly thrown up in the water fountains and sparing life 


\section{International Journal of Science and Research (IJSR) \\ ISSN (Online): 2319-7064 \\ Index Copernicus Value (2013): 6.14 | Impact Factor (2014): 5.611}

to groves which surround and decorate all hill of Alhambra."[2] In Figure 2. The beautiful view of the Alhambra garden corner is represented: box fences have the geometrical form, corresponding to an Islamic ideal of an order. As the English researcher of Islamic gardens Emma Clark notes.: "...a secret of beauty of gardens of Alhambra - not only in water, but also that it, as well as the architecture, always have "the human scale". Visiting palaces of Alhambra today, you get the first impression about "the human and intimate scale" of water when you enter the first yard, Kuatro Dora-do ("Gold room")."[2] "The Yard of Mexuar» ( Patio del Mexuar) or the yard of «Gold room». Is situated between fountains in its center, represents the big low carved pool from pale marble, diameter $1,5-2 \mathrm{~m}$. On edge of the fountain sixty scallops are cut out it's number is multiple to $12-$ a solar number. Water beats with the bubbling stream from the center of "a lotus bud", making the soft "raging" splashes. The pool is situated in octagonal deepening where to water always flows down as eternal waters of Paradise in the traditional Paradise garden. (Figure 3.).

Myrtaceous yard (Figure 4 Myrtaceous yard. Alhambra) in which there is a big quiet rectangular pool with fountains "in the form of the Yale key" at each end from which thin stream water flows. Around two myrtaceous fences the narrow direct streamlets flowing symmetrically to each other. This yard is a fine example of harmony between architecture, water and green plantings and very is suitable for silent contemplation. Then - the Lion's yard where the central fountain represents big pull, supported by twelve lions, with four water channels following in hundred-krone of the center from four fountains on one on each side of the yard. (Figure 5.)

In Alhambra Mahomed Vth was the patron of creation the «Lions' yard» and in many respects understood deep value of four-part Chor-bag style gardens. Titus Burkhardt gives description of the «Lion's yard» in Alhambra: "The plan of a heavenly garden always includes four rivers of Paradise, flowing towards four quarters of the Sky. Water streams from the «Lions' yard» are filled from four sides: from two halls in the North and the South sides and from under two the stone canopies on the western and east ends. A floor in halls is located above, than the garden so the water flowing from round pools flows down across a threshold to the fountain, where gathers around lions and goes to the ground... The fountain with its twelve lions, that are supporting water tank and throwing up water, represents an ancient symbol which has got to Alhambra from the pre-Christian East. Because the lion who is throwing up water is the sun from which there is a life stream comes up and twelve lions are twelve zodiac signs, twelve months which all together represent eternity.[2] " This remarkable reminder on four rivers of the Edem garden described in the Bible and four paradise rivers described in the Koran. (Figure 6..)

«Lindarakh's yard» is a good example of a combination of architecture, water and plants it was built by Catholics in thirty years after death of the last Mauritian sultan Boabdil. Here the vegetation consists of a box fence with inclusion of coniferous plants and low citrus trees. The visitor receives a deep pacification, from muffled atmosphere, murmur of the fountain, closeness from the high and imposing palace with an arcade through which the Arab quarter al-Baysin is below looked through. Irving described «Lindarakh's yard»: "the lonely small yard or a garden with the alabaster fountain, rosebushes and a myrtle, lemons and oranges [2].

Having left palaces of Alhambra, the visitor appears beside the big quiet pool at the pavilion «Partal» and the «Female tower». As well as in the Myrtaceous yard, there are some small fountains "in the form of the Yale key"[5] with quietly murmuring water here. Then, from this point of perspective the magnificent view on the Generalife opens. The complex of the Generalife in Granada has been constructed in a slope of Serro-del-Sol as the summer country residence for sultans of the Nasrid dynasty approximately in 1319. The site adjoined to Alhambra from where the view of a beautiful landscape opened. Gardens and the pavilion in the Generalife have been constructed very close to the city as the usual country residence for Nasrid sultans, for a privacy rest out of the city noisy palace of Alhambra. The name «Generalife» comes from Arab «Jannat», that means «Paradise» or «garden», and - «Al Arif» that means «knowing» or «architect», thus the name was translated as «A garden of an architect».

The traditional garden on a terrace planned on horizontals is also fenced from the outside world with a wall, extended from the North to the South where the entrance is situated. The plan of a garden displays the central channel with fountains which were used as the tank for ablution by visitors. (Figure 8.) The lonely private garden of a harem, with the U-shaped channel is set with cypresses «Patio de los Cypresses» (Fig 7.) oleanders blossoming in June, in a month when the suite of the Mauritian yard, arrived to the palace. Water ladder marches go down from hill tops overgrown with trees, air is cool the charm from a look and a sound of the falling water is felt. (Figure 10.)

A pearl of the Generalife is the «Yard of the channel»«Patio de la Assequia», (Figure 9.), literally that means «From the Aqueduct». The fenced rectangular garden is put in compliance with Ibn Luyun's recommendation. In the center, there is the towering palace is issued by arches and a beautiful views of Alhambra is opened here. The method of lowered flower beds is used here. Originally in tropical countries this method appeared as an auxiliary factor in order to preserve rain water to watering plants and bushes. In smaller scales this way has been applied in the «Yard of the channel» of Generalife.

In the countries of the Middle East, Central Asia and Mauritian Spain the close principles of creation of architectural spaces, a community in culture and architecture, including gardening art were developed. Here it is possible to refer to the following fair conclusions of G.A. Pugachenkova - honorary academician of Academy of Science of Uzbekistan in which it is said that these principles have been caused by the following factors [6]: 


\section{International Journal of Science and Research (IJSR) \\ ISSN (Online): 2319-7064 \\ Index Copernicus Value (2013): 6.14 | Impact Factor (2014): 5.611}

- Uniformity of process of social development;

- Interlacing of historical destinies; Ethnic and language relationship (Iranian and Turkish group of languages);

- The Uniform Muslim outlook keeping interconnected forms in architecture, an ornament, hand-written painting, and also in planning of the cities;

- Political, commercial and cultural ties of these people; Continuous interchange and interference of art experience.

The religion of Islam introduces feeling of a universal order and the peace as in the Koran it is told that «"Peace" is the only word which to be pronounced in a Paradise garden». Therefore, one of the main functions of "traditional paradise gardens" is creation of the harmonious environment, leaving from terrestrial mercantile cares in meditation, where the soul of the believer would be in a condition of consent with the Creator. Except meditative and contemplate aspect, geometrical drawing of traditional gardens of Mauritania came from: practical requirements to an architecturalgarden complex, traditions of dynasties, an environment of the territory, a district landscape.

Experience of construction of Mauritian gardens specifies that architects of Mauritian Spain projecting gardens, is unsurpassed, were able to hold to the strict plan, to find harmony, balance between architecture and water devices, vegetation and integrated unity of parts and whole.

\section{References}

[1] Francisco Pietro Moreno. LosJardines de Granada. Arte de Espaca, 1983

[2] Irving. Tales from the Alhambra, 1st publ. 1832. Ediciones Miguel Sanchez, Granada, 1994

[3] Кларк Э. Искусство исламского сада. Пер. с англ. М: Издательство «Ниола-Пресс », 2008.

[4] Titus Burckhardt. Moorish Culture in Spain, op. cit., p. 209

[5] Emma Clark. The Art of the Islamic Garden. Ramsbury, Marlborough, «Ниола-Пресс», 2008.

[6] Г.А. Пугаченкова Среднеазиатские сады и парки XV в. Труды САГУ 1951г. вып. ХХІІІ

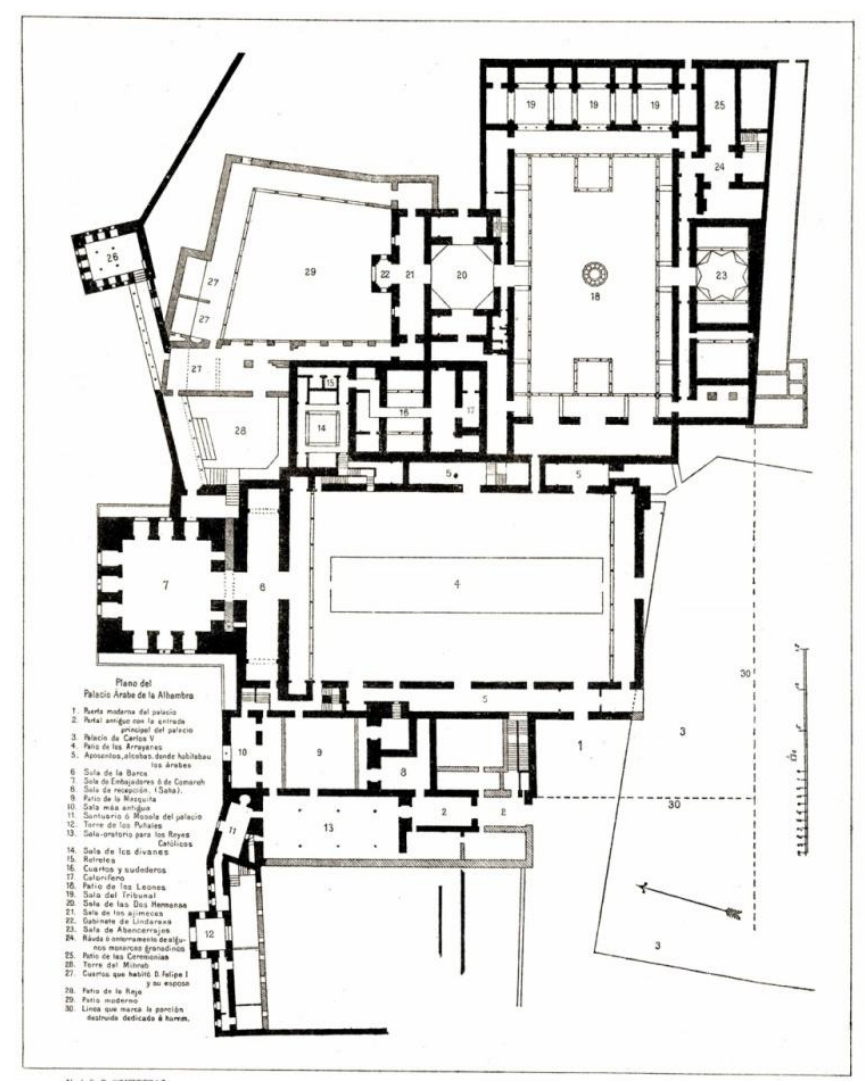

Figure 1: Plan of the Alhambra residence. Explication: A.Glavny entrance, B. First yard, C. Yard of Machuco, D. Mexuar, E. Kuatro Dorado's yard, F. Myrtaceous yard, G.Зал of Ambassadors, H. Lion's yard, I. Hall Mukarabov,

J. Hall of justice, K. Chamber of two sisters, L. Hall Abencerrages, M. The yard with a screen, N. Daraks's garden, O. Charles V's palace (head of 1526)

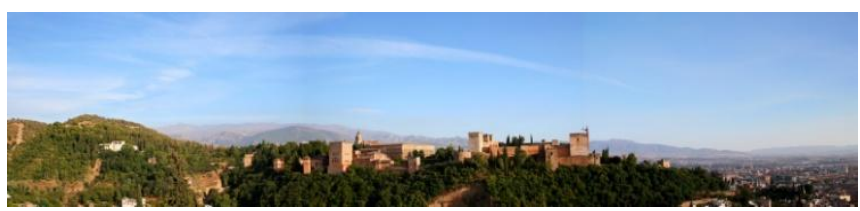

Figure 2: The beautiful view of the Alhambra 
International Journal of Science and Research (IJSR)

ISSN (Online): 2319-7064

Index Copernicus Value (2013): 6.14 | Impact Factor (2014): 5.611

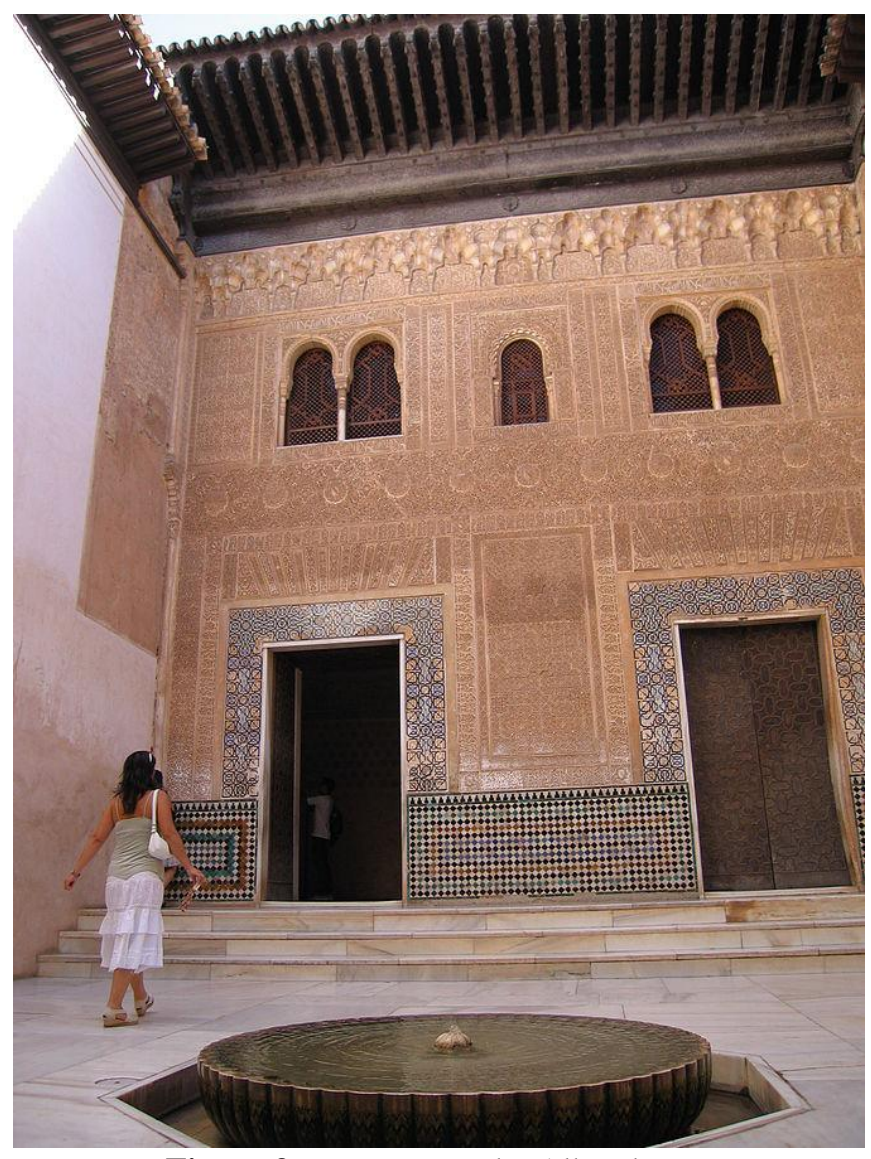

Figure 3: Kuatro Dorado, Alhambra

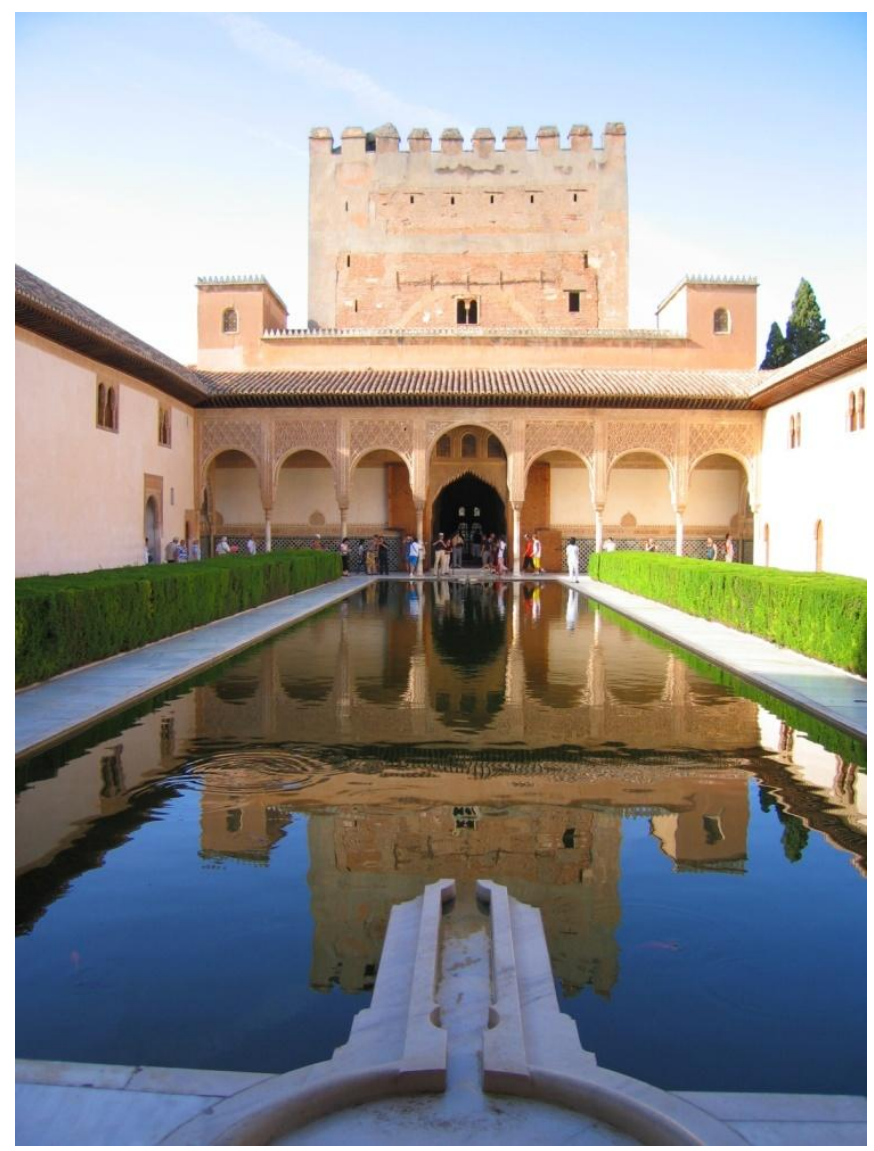

Figure 4: Myrtaceous yard. Alhambra

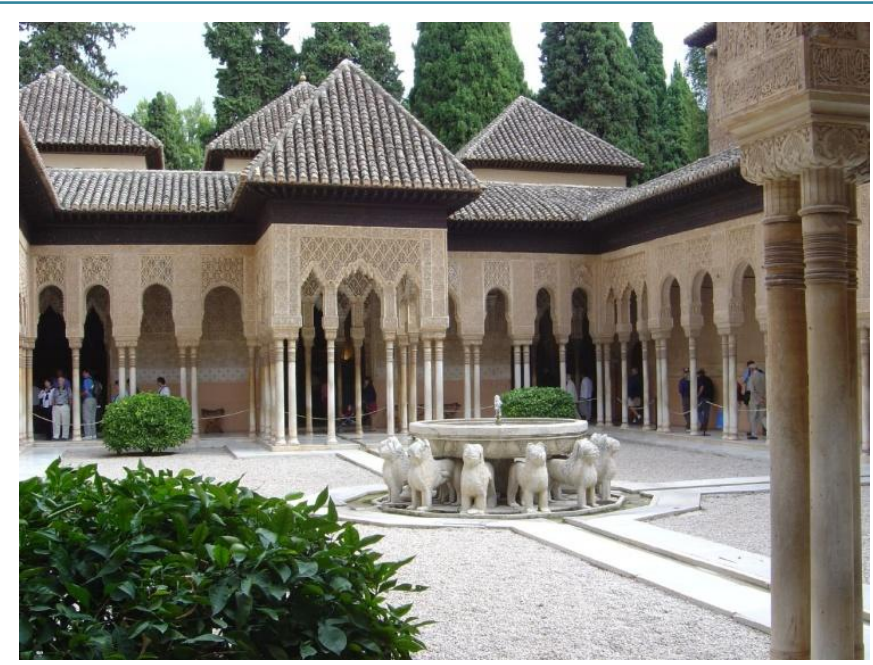

Figure 5: Lion's yard

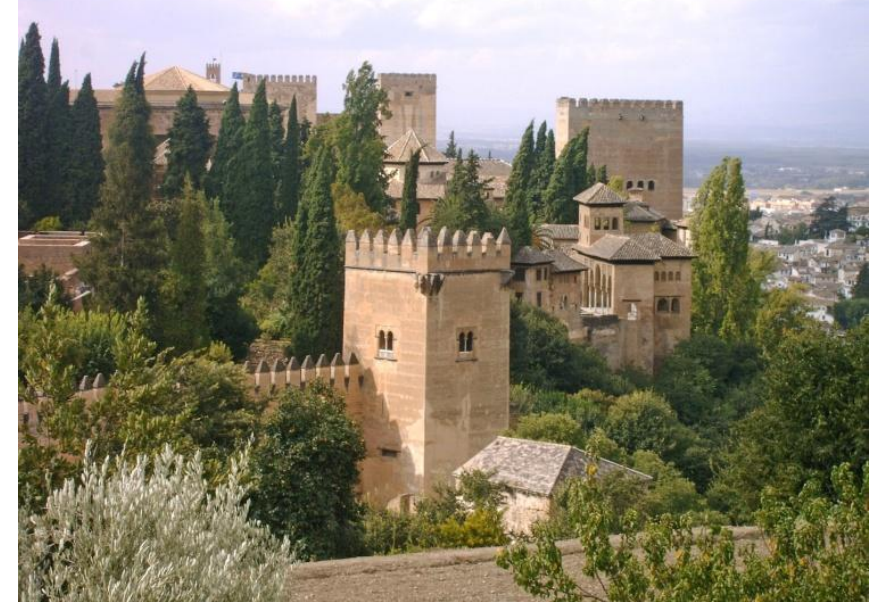

Figure 6: View of Alhambra residence from Generalife palace

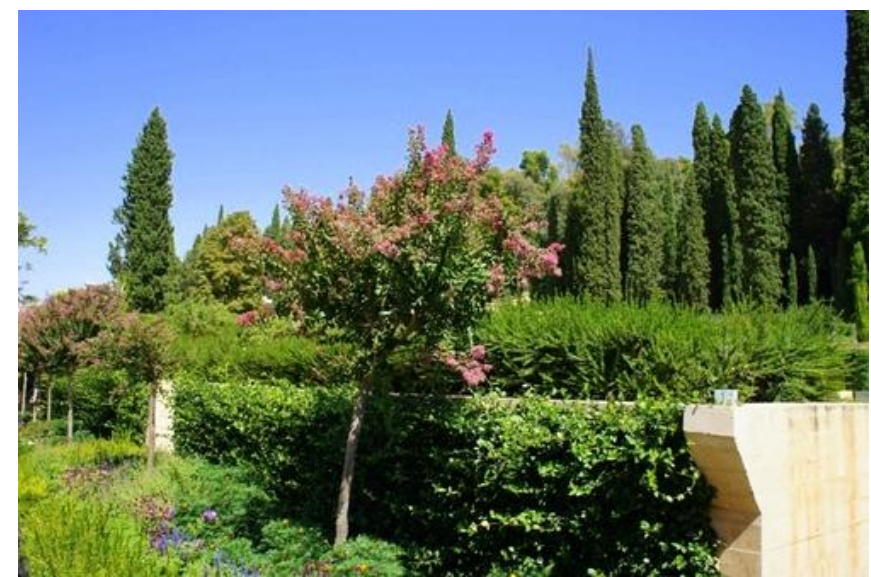

Figure 7: Patio de los Cypresses 


\section{International Journal of Science and Research (IJSR) \\ ISSN (Online): 2319-7064}

Index Copernicus Value (2013): 6.14 | Impact Factor (2014): 5.611

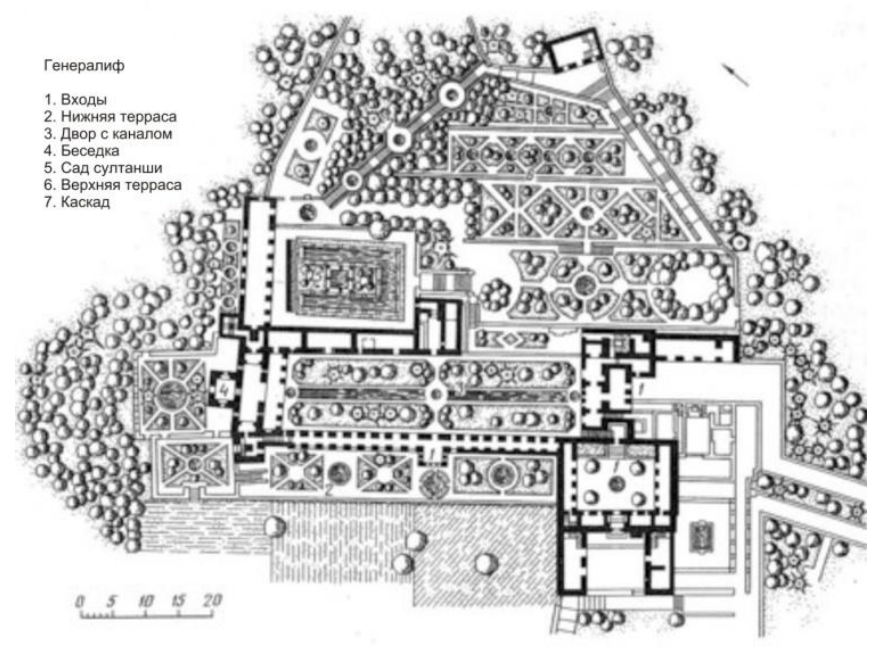

Figure 8: The plan of Generalife palace

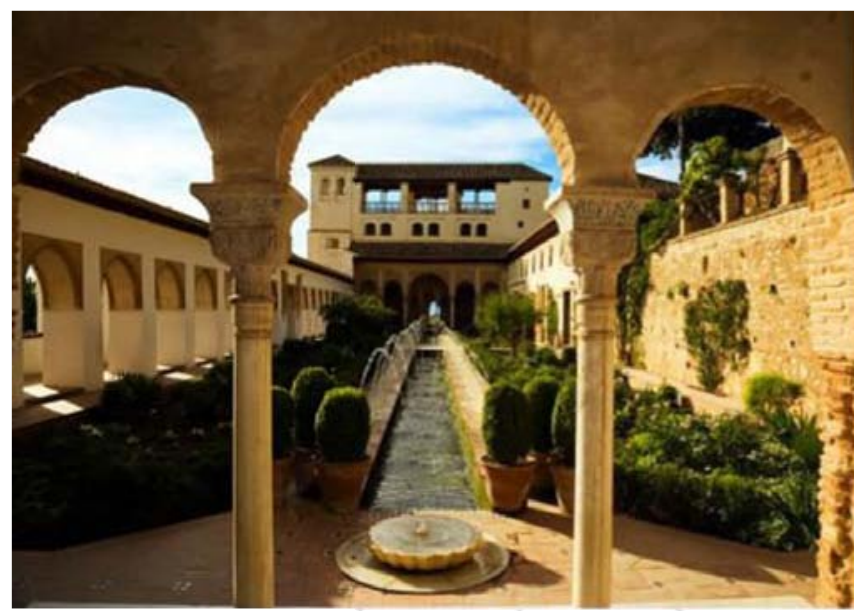

Figure 9: «Yard of the channel»- «Patio de la Assequia»
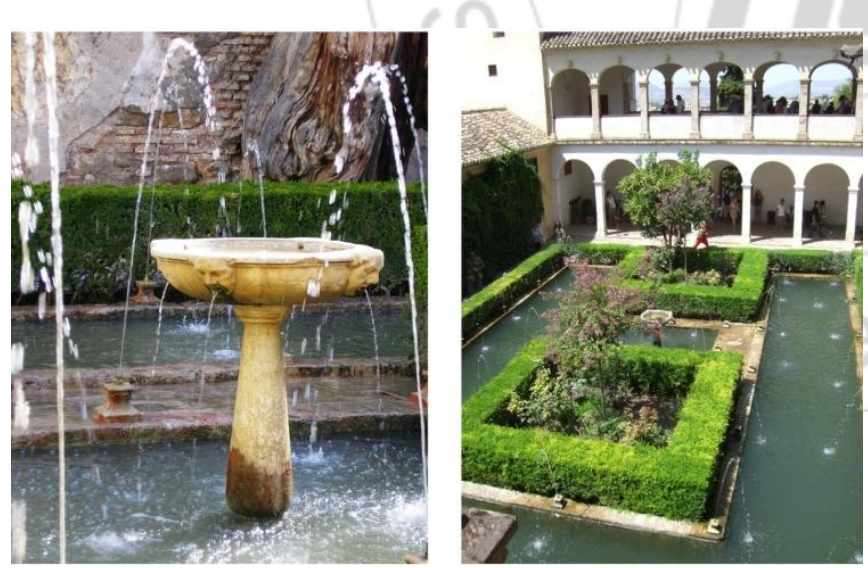

Figure 10: The garden of Sultanees. Generalife 